Florida International University FIU Digital Commons

Cuban Research Institute Events

Cuban Research Institute

8-24-2015

\title{
Puerto Ricans in the Empire: Tobacco Growers and U.S. Colonialism
}

Cuban Research Institute, Florida International University

Follow this and additional works at: https://digitalcommons.fiu.edu/cri_events

Part of the Latin American Studies Commons

\section{Recommended Citation}

Cuban Research Institute, Florida International University, "Puerto Ricans in the Empire: Tobacco Growers and U.S. Colonialism" (2015). Cuban Research Institute Events. 240.

https://digitalcommons.fiu.edu/cri_events/240

This work is brought to you for free and open access by the Cuban Research Institute at FIU Digital Commons. It has been accepted for inclusion in Cuban Research Institute Events by an authorized administrator of FIU Digital Commons. For more information, please contact dcc@fiu.edu. 


\section{Cuban Research Institute \\ \& Kimberly Green Latin American and Caribbean Center}

Steven J. Green School of International and Public Affairs
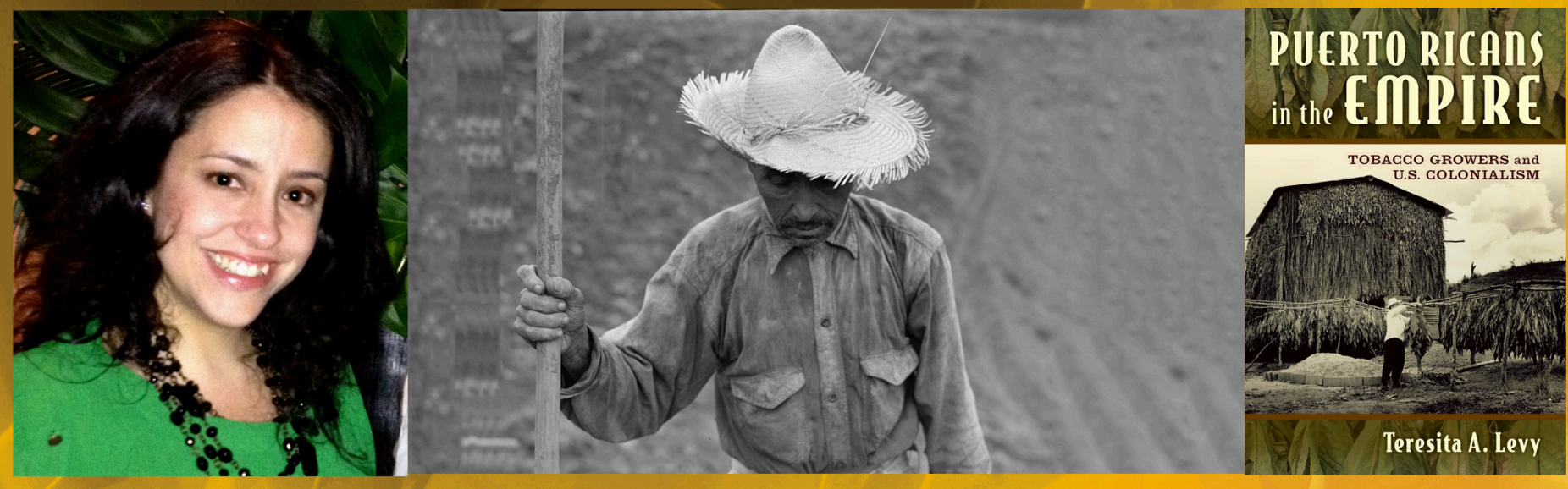

\section{Puerto Ricans in the Empire: \\ Tobacco Growers and U.S. Colonialism}

\section{Book Presentation by Author Teresita A. Levy}

August 24, 2015 | 8:00 PM | Books \& Books | 265 Aragon Ave., Coral Gables

A major contribution to the debate over U.S. colonialism, Puerto Ricans in the Empire shows how Puerto Ricans won inclusion in the empire, in terms that were defined not only by the colonial power, but also by the colonized. Focusing on the tobacco growing industry, Teresita Levy reveals how farmers became an effective political force in the empire, successfully lobbying U.S. administrators in San Juan and Washington, to improve their lives and boost their share of the tobacco-leaf market. The relationship between Puerto Rico and the United States was undoubtedly colonial in nature, but, as Puerto Ricans in the Empire shows, it was not unilateral. It was a dynamic, elastic, and ever-changing interaction, where Puerto Ricans actively participated in the economic and political processes of a negotiated empire.

Dr. Teresita A. Levy is an associate professor of Latin American and Puerto Rican studies at Lehman College, City University of New York, and the associate director of the Center for Latin American, Caribbean and Latino Studies at The Graduate Center. She holds a Ph.D. and M.Phil. in History from the CUNY Graduate Center, an M.S. in Counseling from Long Island University, and a B.A. in Latin American Studies from Rollins College.

This event is free and open to the public. To confirm your attendance and for more information, please call (305) 348-1991 or write cri@fiu.edu. 